\title{
Representações do universo rural e luta pela reforma agrária no Leste de Minas Gerais
}

\author{
Maria Eliza Linhares Borges \\ Departamento de História - UFMG
}

\section{RESUMO}

O presente artigo se propõe a analisar o movimento de mobilização e organização político-ideológica dos setores subalternos do campo, no Vale do Rio Doce, região leste de Minas Gerais no imediato pré-golpe de 1964. Interessanos, especificamente, analisar as representações de mundo dos camponeses mostrando como elas orientaram suas formas de luta pela reforma agrária naquele período.

Palavras-chave: Brasil: reforma agrária; Movimento camponês; Sindicalização rural.

\begin{abstract}
The article analyzes the movement of political-ideological mobilization and organization of the subaltern rural sectors in the Rio Doce Valley, east of the state of Minas Gerais, Brazil, just before the 1964 coup. It aims specifically to analyze the worldviews of the peasants, showing how such views oriented their forms of struggle for land reform at that period.
\end{abstract}

Keywords: Brazil: Land reform; Peasant movement; Rural trade-unionism.

A homogeneidade — de resto parcial — da cultura de uma determinada sociedade é vista como ponto de partida e não como ponto de chegada de um processo coercitivo e, enquanto tal, violento.

Carlo Ginzburg

Entre as muitas estórias e histórias sobre os acontecimentos que antecederam o movimento político-militar de março e abril de 1964 consta que, lá pelas bandas do rio Doce, próximo à cidade de Governador Valadares, no leste de Minas Gerais, um proprietário rural quase chegou a ser enterrado vivo, em sua própria fazenda, por um grupo de camponeses integrantes do movimento de luta pela reforma agrária. 
Nos meses anteriores ao golpe de 1964 esse relato transcendeu os limites do município. Sob forte emoção, foi repetido no interior dos círculos familiares daqueles que, em fins de 1940 e nas décadas seguintes, se haviam estabelecido nas matas do Vale do Rio Doce, antigo refúgio dos índios botocudos, e ali dado início ao comércio de madeiras e à pecuária de corte. Na década de 1980 tivemos a oportunidade de viajar pela região, percorrer os arquivos dos jornais locais e entrevistar tanto a liderança dos proprietários rurais envolvidos no combate à luta pela reforma agrária e ao sindicalismo rural, quanto alguns dos integrantes do Sindicato dos Trabalhadores Rurais de Governador Valadares e de Galiléia, onde conhecemos dois integrantes do grupo de camponeses que teria pretendido enterrar vivo aquele proprietário rural de Governador Valadares. ${ }^{1}$

Para muitos de nossos entrevistados, a imagem de um proprietário rural empunhando um enxadão e cavando sua sepultura para ser enterrado vivo não só explicava a polarização de interesses ocorrida na cidade, entre janeiro e março de 1964, como também justificava a violência que marcou o cotidiano de Governador Valadares e dos municípios vizinhos no imediato pós-golpe. Na visão de alguns atores locais, entre fevereiro e março daquele ano o país perdera a noção dos parâmetros reguladores da ordem social; o espectro do comunismo dirigia as ações de demagogos e defensores da anarquia e o medo rondava os lares então ameaçados pela ação de indivíduos e grupos de subversivos. Para conter o alastramento de tal descontrole político e social, os proprietários fundiários do Vale do Rio Doce seguiram o exemplo de seus parceiros da indústria, do comércio, dos bancos e da área política de outras regiões de Minas Gerais e do Brasil, e uniram-se aos militares. A "Revolução de 1964" teria sido o desdobramento natural dessa ação conjunta em defesa da ordem.

Nesse mesmo período, os textos e as imagens dos jornais locais dão a ver uma cidade partida ao meio. De um lado estavam os proprietários rurais e seus familiares, a Igreja e o poder público local; de outro, os quase dois mil membros do Sindicato dos Trabalhadores Rurais, constituído não apenas por meeiros, parceiros e assalariados do campo, mas também por moradores das favelas de Governador Valadares, quase todos egressos das áreas rurais. Enquanto a liderança patronal congregava a classe na sede da Associação Rural de Governador Valadares, as ruas do centro da cidade iam se transformando numa espécie de extensão do espaço privado e religioso dos lares latifundistas. Munidas de panelas e terços ou empunhando faixas com dizeres moralizantes, esposas e filhas dos proprietários fundiários, muitas delas acompa- 
nhadas de suas empregadas domésticas, davam um colorido especial às Marchas com Deus pela Pátria e a Família. Simultaneamente, na periferia da cidade, uma centena de membros dos setores subalternos do campo fazia vigília na sapataria do Chicão (Francisco Raimundo da Paixão), então transformada em sede do Sindicato dos Trabalhadores Rurais de Governador Valadares. Dentro e fora dela o assunto era um só: a reforma agrária, na lei ou na marra.

Como se sabe, toda essa movimentação integrou um contexto histórico marcado, externamente, pela guerra fria e, internamente, por uma intensa mobilização político-ideológica em torno das chamadas Reformas de Base do governo do presidente João Goulart. Para uns, a realização dessas reformas inauguraria uma nova era, gerida por um governo democrático e popular, condição para a deflagração da Revolução socialista. Para outros, as tais reformas eram sinal de um tempo de anarquia moral, social e política. Para ambos, a mobilização e a organização política dos diferentes setores da sociedade era condição necessária para garantir o futuro segundo as previsões de cada grupo.

Se essa era a percepção de uma parcela significativa dos atores, o cruzamento e a análise da documentação de época, com fontes sobre a história da região e com fontes orais, produzidas já na década de 1980, aponta-nos uma realidade bem mais complexa que aquela que brota do olhar deste ou daquele ator envolvido nos acontecimentos de então. Entre os diferentes aspectos do processo de mobilização e organização dos trabalhadores rurais do Vale do Rio Doce, há que se destacar que os integrantes dos setores subalternos do campo tiveram uma compreensão própria do papel e da função dos sindicatos de trabalhadores rurais na luta por seus direitos. A versão de um dos envolvidos na estória/história que inicia este artigo é uma das evidências da assimilação particularizada que eles possuíam dos sindicatos.

Mais que analisar os diferentes ângulos do processo de mobilização político-ideológica que fez de Governador Valadares uma das regiões mais aguerridas de Minas Gerais no pré-golpe de 1964, interessa-nos, neste artigo, entender as razões histórico-culturais que fizeram do movimento de sindicalização rural um meio de luta pela retomada de um modus vivendi próprio da representação de mundo dos camponeses. Como se verá mais adiante, essa singularidade da luta sindical das regiões do Vale do Rio Doce, certamente ocorrida em outros lugares, não apenas entrava em choque com os interesses fundiários, como também se distanciava da visão que as lideranças do PCB e da AP tinham dos sindicatos na luta política do período. 


\section{O VAle do Rio Doce E A IDEOlOGia DA TERRA COMO BEM ILIMITADO}

A vasta área de terras que formava os sertões do leste (formada pelas áreas hoje correspondes aos Vales do Jequitinhonha, do Mucuri e do Rio Doce e de parte da Zona da Mata mineira), além de apresentar alto grau de insalubridade e de ser recortada por cachoeiras que dificultavam a navegação, era hábitat da "ferocidade do gentio Botocudo". Entre 1789 e 1805, as autoridades metropolitanas e seus representantes na colônia passaram a estudar a promoção de políticas destinadas a incentivar a ida de agricultores e comerciantes para lá. A principal razão para tais providências era a queda da produção aurífera e diamantífera da Capitania de Minas Gerais.

Em maio de 1808, a coroa recém-instalada no Brasil declara guerra ofensiva ao gentio ao mesmo tempo em que lança as bases para a colonização das áreas dos sertões do leste. Entre as medidas tomadas, oferecia-se isenção de pagamento de dízimos por dez anos e moratória de seis anos aos devedores da Fazenda Real, além da liberação de taxas de importação e exportação dos produtos a serem comercializados através do rio Doce. Aos fazendeiros que para lá se deslocassem também era facultado o uso do trabalho indígena. Apesar das vantagens oferecidas, poucos foram os que se aventuraram a adentrar aquela fronteira da Capitania. Após a Independência do país, D. Pedro I ofereceu outras vantagens para estimular a colonização da região. Embora a suspensão do regime sesmarial date de 1822, um documento de 1824 indica que estava facultada a concessão de sesmarias a todos os que, até 1836, se dirigissem para a região do rio Doce e ali se dispusessem a cultivar a terra e a comercializar seus produtos. ${ }^{2}$

Segundo alguns estudiosos, enquanto durou a concessão de sesmarias na região, muitas foram as lutas entre os novos donos da terra, os sesmeiros, e os que lá já se achavam instalados e não detinham título de propriedade. Mais de um século depois, a região do Vale do Rio Doce, embora já incorporada ao mundo chamado civilizado, ainda continuaria a ser palco de disputas entre posseiros e proprietários fundiários.

Antes, porém, as terras e águas dos Vales do Doce e do Mucuri abrigaram outros sonhos e outros projetos. Já em 1857 achava-se concluída a estrada que ligava Diamantina a Filadélfia (atual cidade de Teófilo Otoni). Sua construção fora motivada por dois projetos a cargo do deputado geral do Império, Teófilo Otoni. O primeiro destinava-se a catequizar os indígenas da região, e o segundo, a construir uma nova província que, a partir de uma rede de estradas, haveria de permitir o escoamento dos produtos mineiros para 
outras regiões do país, através do porto de Vitória, no Espírito Santo. Uma saída para o mar era tudo o que a Província de Minas Gerais necessitava, segundo Teófilo Otoni, para superar o atraso econômico que tanto maltratava sua gente. É nessa conjuntura que se funda a Companhia de Navegação do Mucuri. ${ }^{3}$ Ainda que esse projeto não tenha se concretizado, a construção da estrada viabilizou a instalação de uma colônia de imigrantes alemães na década de $1850^{4}$ e, vinte anos mais tarde, permitiu a chegada dos missionários capuchinhos que fundaram um colégio para catequização do gentio e dos filhos dos colonos em Itambacuri.

Nos primeiros anos da República, a região recebe um grande contingente de migrantes em função da construção da ferrovia Vitória-Minas, então chamada, Vitória-Diamantina. Em 1904 a movimentação de seus trilhos encontrava-se próxima de Figueira do Rio Doce (atual Governador Valadares). ${ }^{5}$ $\mathrm{Na}$ década de 1930, essa via de entrada de migrantes achava-se em pleno funcionamento.

A vila de Porto de Figueira do Rio Doce, que em 1822 não era mais que um "amontoado de casas", em 1938 passava a cidade sob a denominação de Governador Valadares em homenagem ao então Interventor Federal em Minas Gerais, Benedito Ribeiro Valadares. Conhecida como A Princesa do Vale, a cidade daria seqüência à sua marca histórica, ou seja, continuaria a ser uma espécie de receptáculo de migrantes, pobres e ricos, todos interessados em ali reproduzir suas utopias de exploração da terra. Ao invés da luta entre pobres livres e sesmeiros, marca do período imperial, a partir da década de 1930 e sobretudo da de 40, o casamento entre latifúndio e indústria (siderurgia) garantiria aos proprietários rurais uma sobeja vantagem no conflito com os posseiros da região. Não por acaso, os antigos da região costumam dizer que os indivíduos que a febre amarela não exterminou, a terra fértil e valiosa abrigou, desde que os interesses dos coronéis locais e de seus grileiros fossem respeitados. Até os anos 40, aproximadamente, a região do Vale do Rio Doce produziu café, cana-de-açúcar, fumo e algodão, além de plantar mandioca, batata, arroz, milho e feijão, oriundos quase sempre da economia de subsistência a cargo dos posseiros locais. Daí em diante, a região foi se tornando uma das principais áreas da pecuária bovina de corte, além de sediar a instalação de empresas de capital nacional e estrangeiro - como as siderúrgicas Belgo-Mineira, Acesita, Companhia Vale do Rio Doce e outras destinadas à extração e à exploração da mica e do berilo.

Além da ferrovia Vitória-Minas, a construção da rodovia Rio-Bahia (BR-116), nas décadas de 1950 e 60, muito contribuiu para a chegada dos mi- 
grantes que, com ou sem capital, fizeram da região uma imensa fronteira em movimento, regida pela ideologia da terra como um bem ilimitado. ${ }^{6}$

Os trechos de entrevistas aqui reunidos dão-nos uma idéia da diversidade das motivações que, no pós-Segunda Guerra Mundial, animaram a ida dos dois principais atores do universo rural para a região, a saber, os posseiros e os latifundiários. Conforme os dois primeiros entrevistados, aquelas terras significavam a possibilidade de enriquecimento fácil e rápido. Ouçamos estas falas:

As matas do Vale do Rio Doce eram perigosas por causa do impaludismo. Mas foram desbravadas rapidamente. À proporção que saía a madeira, plantava-se milho e arroz e, após a primeira colheita, no lugar das lavouras o fazendeiro não conseguia replantar. Nós combatíamos o [capim] colonião como se fosse uma praga. Em pouco tempo nós compreendemos que compensava mais criar gado do que plantar. Com o colonião nativo o fazendeiro tinha lucro sem gastar, era só cercar a terra ? $^{7}$

Numa visão mais crítica, um dos advogados dos proprietários rurais de Governador Valadares chama a atenção para o fato de que

À medida que as matas foram ficando distantes e tornando desvantajosa a extração da madeira e que o comércio de mica foi perdendo interesse para o mercado internacional, a pecuária foi se tornando a atividade principal ... A lavoura existente nas fazendas era de sobrevivência, o fazendeiro não queria investir. Só queria lucro, mal davam sal ao gado. As fazendas de Governador Valadares não tinham nem sede, era só uma casinha e em torno dela não tinha nada plantado. ${ }^{8}$

Já para os indivíduos egressos do universo camponês, a fertilidade daquelas terras estimulava outro tipo de busca. Significava a possibilidade de deixar para trás uma vida de meeiro, parceiro ou empregado rural para se tornar um pequeno proprietário, dedicar-se à agricultura que, no universo camponês, é sinônimo de terra liberta, de fartura e felicidade. Todavia, conforme nos relata um funcionário da Secretaria da Agricultura de Minas Gerais, com o passar do tempo

o posseiro, gente humilde, pobre, achou que entrando na terra e fazendo um aberto, plantando etc., seria dono da terra. Mas aconteceu que vieram os grandes, poderosos e tocaram esse povo de qualquer jeito. Compravam ou abriam um pedaço na mata e depois partiam por cima dos outros ... Tocavam o sujeito para fora impiedosamente, o sujeito com família e tudo. Às vezes, gente que mo- 
rava ali há 10 ou 15 anos. Mataram demais, quebraram esse povo de lá de qualquer maneira. Queimaram barracos e tocaram eles sem dó. ${ }^{9}$

Ao "acolher" sonhos tão diferenciados, as terras do Vale do Rio Doce foram se constituindo em locus da implantação de diferentes fronteiras socioculturais, veiculadora, cada uma delas, de utopias também distintas. Essa variabilidade de percepção de mundo contava com um limite muito forte: o casamento entre latifúndio e indústria, chancelado pelo Estado. ${ }^{10}$ Era esse enlace que regia a correlação de forças, claramente desigual, ali existente.

No alvorecer dos anos 60, praticamente inexistiam terras devolutas e/ou por serem ocupadas na região. Os posseiros que não migraram para as cidades vizinhas nem se assalariaram nas indústrias siderúrgicas foram incorporados aos latifúndios como vaqueiros, meeiros e parceiros. ${ }^{11}$ Apenas uma pequena parcela logrou resistir à escalada da concentração da propriedade fundiária e ainda conseguia manter suas pequenas glebas de terras.

Por volta de abril de 1957, após denúncias sobre os excessos cometidos por grileiros na região, o Diário de Minas enviou um de seus repórteres para os vales do Doce e do Mucuri. As matérias do jornalista Mauro de Santayana puseram a nu a situação de impunidade desfrutada pelos grileiros vinculados ou não às companhias siderúrgicas e madeireiras, as quais contavam com o respaldo de Juízes de Paz, deputados, jagunços e policiais. ${ }^{12}$ As imagens de cemitérios cravados no meio das matas, de famílias inteiras sendo assassinadas, de tenentes e coronéis de polícia transformando-se em grandes proprietários rurais da noite para o dia e de Juízes de Paz que jamais eram localizados pelos reclamantes, eram uma demonstração do casamento entre latifúndio e siderurgia, modelo que ainda hoje vigora na região. As resistências que porventura ocorriam eram tratadas como caso de polícia.

Diante da ausência das autoridades nos locais dos conflitos, os grileiros, temporariamente intimidados com as notícias na imprensa, retornaram às suas ações de praxe. Conseqüentemente, os posseiros seguiam reafirmando sua descrença na justiça. Não por acaso, suas conversas eram constantemente permeadas por relatos de outros sobre o tempo dos movimentos messiânicos, do cangaço e do banditismo social em geral. Ao evocar o que eles chamavam de feitos heróicos "dos tempos do Capitão Virgolino", ou mesmo, do "tempo de Lampião [em que] se podia fazer com o fazendeiro o mesmo que ele faz com a gente, [pois] ele só entende de tiro", ${ }^{13}$ muitos de nossos entrevistados tendiam a mesclar essas memórias coletivas com passagens da Bíblia, cuja interpretação era permeada por uma idéia paradisíaca da terra, por eles 
percebida como sinônimo de fartura e felicidade. Enquanto vigiam impunidade e injustiça social, crescia a insatisfação e um profundo sentimento de perda de valores e hábitos próprios da identidade camponesa.

Impossibilitados de fazer do diálogo com o "outro" - com os grandes proprietários rurais e seus aliados - um recurso legítimo para sua independência no campo, restavam-lhes apenas três saídas. A primeira seria continuar no campo como assalariado e ser leal a seu patrão, já que a tradição autoritária dos setores latifundiários não permitiria o uso da voz para melhorar a situação do trabalhador dentro da propriedade alheia. A segunda opção seria deixar suas terras para novamente buscar outra área de fronteira agrícola e nela reiniciar a luta pela manutenção do modo camponês de viver. E, a terceira, seria deixar suas terras, recusar-se a se transformar em empregado rural e ir engrossar as filas do êxodo rural em busca de uma outra vida nas áreas urbanas. Na realidade, tanto na opção de ficar, quanto na de sair em direção aos centros urbanos, o posseiro estava fadado a perder sua identidade camponesa, o que na interpretação dada pelos proprietários fundiários locais sobre o processo de desenvolvimento da economia agrária era, como demonstra a fala do presidente da Associação Rural de Governador Valadares (1963-64), “um fator natural”:

As terras destas regiões foram sendo abertas, os pequenos proprietários foram vendendo suas terras e indo para as cidades ou ficando nas roças como meeiros, parceiros e até vaqueiros. Isto acontece em toda a região de pecuária ... é um fator natural, onde entra o boi, sai o homem ... é um fator natural ... O boi precisa de espaço e sujeito precisa sempre adquirir mais terras para poder aumentar o rebanho. ${ }^{14}$

Em novembro de 1957, as tensões entre posseiros e grileiros tinham se agravado. A região de Governador Valadares assemelhava-se a um barril de pólvora. Na tentativa de conter os ânimos locais, bem como de dar satisfações a seus eleitores, o governo do estado enviou para a região "um esquadrão de cavalaria”. Um mês depois, o Secretário de Agricultura do governo Bias Fortes (PSD) foi convidado pela Assembléia Legislativa de Minas a esclarecer sobre o andamento dos processos de legitimação de terras na região. Além de reconhecer o descaso do poder público, que segundo o depoente se mantivera "inerte ante as usurpações que se processavam autoritária e desordenadamente", ${ }^{15}$ o então Secretário de Agricultura, Álvaro Marcílio, informou sobre a existência de 14 mil processos de legitimação de terras pendentes na Secre- 
taria. Simultaneamente, deu ciência da criação de "uma comissão especial de sindicância e análise, destinada a agilizar tais processos". ${ }^{16}$ Segundo o governo, seu objetivo era reinstaurar a paz e a justiça na região. Por isso, desde que comprovadas as irregularidades - argumentavam os representantes do poder público estadual - , nem os grandes proprietários, nem as grandes empresas siderúrgicas (ambos acusados de invadir terras de posseiros) seriam poupados. ${ }^{17}$

De acordo com E. P. Thompson, a eficácia da lei depende da capacidade de mostrar sua independência diante de manipulações flagrantes. Parecer ser justa, é uma das condições de sua legitimidade, demandada mesmo por setores que a utilizam em favor próprio. ${ }^{18}$ Tudo indica que as ações do governo Bias Fortes não foram muito além da retórica da independência e da universalidade da lei. Os jornais da capital mineira, sobretudo o Diário de Minas, continuaram, por mais alguns meses, a informar sobre os conflitos entre posseiros e grileiros na região do Vale do Rio Doce, sem que nada tivesse sido feito efetivamente.

Diante do vazio da ação pública, a imagem da lei como imperativo universal e garantidor da igualdade de direitos ia caindo em descrença e o êxodo rural ou o assalariamento dos posseiros parecem ter sido as saídas possíveis. Tanto é que nesse período o então Prefeito de Governador Valadares (19591962), o médico Raimundo Albergaria, filiado ao PSD, deu início a uma política de cadastramento para posterior recebimento de lotes urbanos àqueles que, expulsos da área rural, dirigiam-se para a cidade de Governador Valadares. Taxado de comunista por alguns proprietários rurais, Albergaria buscava, na realidade, criar um mínimo de condições para reter essa mão-de-obra na cidade e, ao mesmo tempo, impedir a criação de focos de tensão social.

Nesse mesmo período, entre 1959 e 1961, as Atas de Câmara Municipal de Governador Valadares oferecem uma visão dos temas considerados importantes para os representantes dos interesses municipais. Discutiam-se e votavam-se assuntos referentes à administração do município, tais como: pavimentação de ruas; policiamento dos bairros, praças e pontes; subvenção às instituições escolares e filantrópicas; construção da nova rodoviária, do aeroporto e do matadouro municipal. Os políticos locais, principalmente os do PSD e os da UDN, tampouco se descuidavam da representação dos interesses ligados diretamente aos grandes proprietários rurais. A vacinação do gado, a contratação de veterinários e a construção para a passagem de bois, eram temas recorrentes nas atas daquela casa.

Vista através dos registros da Câmara Municipal, a Princesa do Vale, como 
era chamada a cidade, parecia finalmente ter encontrado seu ponto de equilíbrio. Nenhum problema de ordem social ou política parecia perturbar a tranqüilidade do cotidiano dos moradores. Essa mesma sensação de paz e ordem achava-se presente no livro de assinaturas das Atas das Reuniões da Associação Rural. O comparecimento, diminuto, dos fazendeiros às reuniões ordinárias, era indício de que a maioria deles achava-se acantonada em suas propriedades.

Mas, em fins de 1961, um acontecimento viria quebrar essa tranqüilidade aparente. Nas matas do Urupuca, município de Itambacuri, região vizinha a Governador Valadares, um camponês, ameaçado seguidamente de expulsão de sua terra, mataria um dos maiores grileiros da região, Horácio Luz. ${ }^{19}$

Diante das repercussões do caso Horácio Luz e do crescimento dos movimentos de mobilização e organização política dos trabalhadores urbanos e rurais no país, os proprietários rurais do Vale, sob a liderança da Associação Rural de Governador Valadares, deram início a uma série de atividades destinadas a fazer do debate sobre política agrícola um meio de deslegitimar a luta pela reforma agrária. No jornal local, Diário do Rio Doce, multiplicavam-se as reportagens sobre crédito e financiamento agrícolas; as vantagens do sindicalismo democrático e sua vinculação com a Igreja Católica; a necessidade de regulamentação jurídica das formas camponesas de arrendamento rural etc. Simultaneamente, a Associação se empenhava na preparação de uma grande concentração ruralista, cuja finalidade seria debater sobre os rumos das propostas em torno da reforma agrária. O desinteresse inicial por parte da maioria dos ruralistas sediados em Valadares, bem como a ausência de representantes de outras regiões nos eventos realizados, não arrefeceu o ânimo dos líderes da classe..$^{20}$ Estes e seus aliados continuaram a utilizar-se do jornal para mostrar a todos como "age o comunismo", quais eram os "caminhos do totalitarismo bolchevique" e por que Valadares deveria unir-se aos "verdadeiros democratas" e votar a favor do parlamentarismo.

A vitória do presidencialismo, em janeiro de 1963, seria um duro golpe para os representantes da classe. A figura de Goulart, imediatamente associada à de Leonel Brizola, era sinônimo de reforma agrária. Mais que isso, significava o rompimento da hegemonia do modo latifundista de vida, vigente naquela região desde as primeiras medidas destinadas à sua colonização. A partir daí, as tensões latentes tornaram-se manifestas, e termômetro social e político-ideológico da cidade acusaria temperaturas cada vez mais elevadas.

Para agravar a situação, o crescimento das Ligas Camponesas no Nordeste, sob a chefia de Francisco Julião, e os esforços do Partido Comunista e, em Minas Gerais especificamente, da Ação Popular (AP), na criação dos Sin- 
dicatos de Trabalhadores Rurais, ${ }^{21}$ reacenderam, nos deserdados da terra, a esperança de finalmente tornar realidade a utopia camponesa. ${ }^{22}$ Pode-se dizer que a partir daí a cidade viveria dias muito conturbados, com repercussões na capital do estado e em Brasília.

\section{SINDICATO DOS TRABALHADORES RURAIS E UTOPIA CAMPONESA}

No Bar do Boi, nome dado ao café onde os proprietários fundiários se reuniam para realizar seus negócios e trocar idéias sobre a situação política do país e da região, bem no coração da cidade, corria à boca pequena a notícia de que o presidente João Goulart estava prestes a decretar a reforma agrária. Na mesma ocasião, Francisco Julião iria à cidade e, num comício em praça pública, conclamaria os camponeses da cidade e da região a lutarem pela reconquista de suas terras. Enquanto isso, em Belo Horizonte estavam em andamento os preparativos para a realização do I Congresso Nacional de Lavradores e Trabalhadores Agrícolas, que contou com a participação de diversos dirigentes sindicais da região do Vale do Rio Doce.

Diante desse contexto, a elite local, através da Câmara Municipal, tratou de estreitar suas relações com o governador da Guanabara. Os inflamados discursos de Carlos Lacerda contra as Reformas de Base e, sobretudo, contra o presidente da República, fariam dele o modelo de chefe do Executivo. ${ }^{23}$

Em fins de 1963, as lideranças fundiárias do Vale encontrariam uma razão imediata para envolver parte dos proprietários interessados apenas em seus negócios privados. Um membro do Sindicato dos Trabalhadores na Extração de Mica foi procurado por trabalhadores da fazenda CREIA - Companhia Rio-docense de Exploração de Imóveis e Agropecuária. Queriam saber que direitos tinham como trabalhadores da firma, conta-nos o miqueiro Sr. Raimundo. Eles eram parceiros e meeiros nessa firma de loteamento e plantação de cana-de-açúcar. Como o funcionário do Sindicato não soube responder às perguntas dos trabalhadores, estes decidiram se aconselhar com o dono da banca de jornal instalada na esquina de Moscou, nome dado ao espaço de trabalho de "Seu João da Banca", como era conhecido esse jornaleiro, membro do PCB. A partir daí, foram tomadas as providências para a criação de um outro sindicado. Foi aí, disse-nos o entrevistado, que

O Raimundo criou uma fila, uma quantidade de gente que dava para criar uma comissão provisória e o sindicato começou a existir. Mas não foi com faci- 
lidade, a gente já vinha planejando há muito tempo para criar um sindicato rural, era uma tarefa do partido, mas nós não conseguíamos de jeito nenhum ... naquele vai-e-vem a coisa andou depressa. Com o objetivo de ter terra, aí já foi esquentando. Eles entraram com uma luta pela terra. Nós pregava para eles que a previdência social ia chegar no campo, que eles ia ter terra, ia ter assistência, que isso é que o Governo Federal prometia pra gente. ${ }^{24}$

A essa altura, freqüentava as reuniões um sapateiro de origem camponesa, membro do PCB: Francisco Raimundo da Paixão, mais conhecido como Chicão. Dentro em breve, posseiros, ex-posseiros a trabalhadores agrícolas da região veriam nele a possibilidade de reconquistar as terras perdidas. Mas ainda naquele momento, a orientação do PCB era fazer do Sindicado um espaço de luta por direitos trabalhistas. A reforma agrária seria decorrência da implantação de um governo democrático, popular e nacionalista.

Em menos tempo do que o previsto, a idéia, não se sabe de quem, de tomar a Fazenda do Ministério, nas proximidades de Governador Valadares, ganhou força entre diversos membros do sindicato. Discordando da proposta, o miqueiro decidiu-se a não mais permanecer à frente do sindicato. Foi exatamente aí que Chicão surgiu como o novo presidente do órgão. "Aí o movimento do Chicão foi só crescendo ... Ele continuou falando com muita coragem. O que ele fez não foi brincadeira”, ${ }^{25}$ lembra o miqueiro, ex-presidente do sindicato.

Segundo nos foi possível apurar, parece que as lideranças do PCB na região não tinham confiança no novo dirigente sindical. Egresso da área rural, Chicão fazia uma leitura particular do órgão. Diferentemente da orientação do partido, ele era visto como um meio para se lutar pela Reforma Agrária na lei ou na marra, assim como proposto pela Ligas Camponesas dirigidas por Francisco Julião e por parcelas dos militantes da POLOP. Não por acaso, Chicão seria desligado do partido. Todavia, naquele momento, sua palavra era prontamente assimilada pelos sindicalizados, cujos anseios eram por ele representados. Os quase dois mil sindicalizados, saídos do campo e das favelas de Governador Valadares, percebiam que os direitos trabalhistas não correspondiam ao direito que eles julgavam valer uma luta, ou seja, a reconquista das terras perdidas. ${ }^{26}$

Havia uma espécie de quebra de encantamento, de falta de sintonia, entre as propostas saídas das lideranças da cidade - notadamente do PCB e da $\mathrm{AP}$, que à época viajavam pela região fundando sindicatos rurais - e as expectativas dos sindicalizados. Ainda que de forma precária, como veremos 
mais adiante, o sindicato, através da figura de Chicão, foi se firmando como um espaço para a luta pela reforma agrária. Já em fevereiro de 1964, o PCB não tinha nenhum controle sobre o sindicato. A fala de um dos diretores do Sindicato dos Trabalhadores Rurais de Santa Cruz, município de Galiléia, é representativa da motivação que fazia crescer a lista de sindicalizados dentro e fora de Governador Valadares. Segundo ele,

Naquela época nem em Santa Cruz, nem em Valadares tinha mais posseiro, a maioria era empregado. Tinha muito vaqueiro e meeiro, os que ainda tinha terra era muito pouco. Mas o trabalhador que trabalha na terra tem aquela vontade de ter terra pra trabalhá pra ele, né? Eh!, ele tem aquela vontade e o sindicato era para a reforma agrária, era uma luta pelo direito, era para beneficiar a todos que não tinham. ${ }^{27}$

Da mesma maneira que ficar nas fazendas de gado como meeiro, parceiro e/ou como vaqueiro significava a perda da identidade camponesa dos posseiros locais, sindicalizar-se também era uma forma de alterar a identidade sociocultural desse ator social. Afinal, o propósito dos sindicatos de trabalhadores rurais era estender para as áreas rurais os direitos trabalhistas já existentes para o proletariado urbano. Não resta a menor dúvida de que a criação de sindicatos de trabalhadores rurais representava uma conquista e um avanço nas relações de dominação nas áreas rurais. Até aquele momento, o empregado rural sequer tinha direitos trabalhistas. Não havendo um foro específico para a arbitragem dos conflitos, esses trabalhadores ficavam à mercê da autoridade de seus patrões.

Todavia, o que aqui estamos discutindo é algo diverso. Nossa intenção é ressaltar a inexistência de condições para que os camponeses pudessem viver segundo a representação que tinham de sua tradição cultural. Idealizada ou não, era ela que sustentava individualidade e garantia identidade social e cultural desse setor da sociedade. Portanto, naquele momento, a criação de Sindicatos de Trabalhadores Rurais se apresentou, para muitos camponeses, como o único espaço de luta possível para criar as condições necessárias à re-criação da utopia camponesa. É importante lembrar que a grilagem de terras, em curso na região, tivera pelo menos dois desdobramentos; o primeiro foi a incorporação de terras camponesas aos latifúndios. Esse processo se dava, em geral, mediante a compra da terra do posseiro que, coagido, vendia sua posse por muito menos que o valor de mercado. O segundo foi a migração desse posseiro para áreas urbanas. Ao se recusar a perder sua identidade cam- 
ponesa e ficar no campo como um trabalhador assalariado, o ex-posseiro assumia outra identidade nas áreas urbanas: passava a integrar o universo do proletariado urbano-industrial.

Diante da impossibilidade de fazer o tempo retroceder, a única alternativa que os ex-camponeses visualizaram naquele momento foi aderir aos Sindicatos de Trabalhadores Rurais e transformá-los em lugar de luta pela Reforma Agrária. Mesmo que as lideranças do PCB e da AP explicassem que esta não constituía a finalidade da luta sindical, os sindicalizados faziam ouvidos "moucos" e ressignificavam os sindicatos. Faziam deles um espaço de execução das propostas que moviam a ação das Ligas Camponesas.

Essa ambigüidade da luta política dos setores subalternos do campo, por nós verificada na região do Vale do Rio Doce, foi, a um só tempo, sua força e seu obstáculo. Em outro artigo tivemos a oportunidade de mostrar como o governo João Gourlart, através de seu Ministro do Trabalho, Franco Montoro, e das lideranças do PCB e da AP, logrou enfraquecer o crescimento das Ligas Camponesas e, simultaneamente, fortalecer a luta pela extensão dos direitos trabalhistas para as áreas rurais. Premido pela conjuntura política, o governo parece ter buscado a solução menos contundente para ir resolvendo a situação daqueles que já trabalhavam, como assalariados, nas áreas rurais no país. ${ }^{28}$ Lembremo-nos de que àquela altura, os próprios posseiros eram unânimes em dizer que na região do Vale do Rio Doce praticamente não havia mais posseiros. Sabe-se que movimentos como os dessa região também existiram no Paraná, nas áreas próximas à barragem do Três Marias, onde sob a liderança da POLOP foi criada a Liga Camponesa de Três Marias, mas que eram hegemônicos no interior dos estados nordestinos e o norte do país, onde tudo indica que havia a maior concentração de camponeses. No Rio Grande do Sul, o governador Leonel Brizola apoiara o movimento dos pequenos proprietários rurais, cuja tradição remontava aos tempos do Império.

Mas voltemos à situação dos sindicalizados do Vale do Rio Doce e vejamos os desdobramentos da convivência, por certo tensa, entre as duas visões sobre o sindicato ali existentes.

Em fevereiro de 1963, ganhou força, entre os sindicalizados, a idéia se tomar a Fazenda do Ministério ${ }^{29}$ como estratégia para apressar a aprovação da reforma agrária e também para garantir terra àqueles que já contavam com suas fichas de sindicalizados. Diante de tal disposição, ao PCB não restou outra solução senão ir negociando o adiamento de tal ato. Enquanto isso, procurava manter o movimento em evidência na imprensa. Ganhar tempo, conter a ira dos proprietários fundiários da região e dar visibilidade ao sindicato, 
parece ter sido a forma encontrada pelo partido para minimizar os riscos que a situação já apontava. Segundo o diretor do jornal estudantil local, $O$ olho,

rondava aquela casa a crença e a esperança de que o governo faria a reforma agrária. Aos poucos foi crescendo o número de sindicalizados. O Chicão sindicalizava todos aqueles que dissessem ser de origem rural. A maioria deles era de fato ex-camponês que vivia na cidade, mas isso era muito complicado ... Eles achavam que os títulos da terra que o Chicão prometia trazer de suas viagens a Brasília e a Belo Horizonte não iam ser suficientes para todos, por isso, permaneciam ali dia e noite. $^{30}$

Dada a situação local e nacional, os proprietários do Vale intensificaram sua mobilização política. Na realidade, não se sentiam ameaçados com o "movimento de Chicão", como costumavam dizer. Estavam bem informados sobre as desavenças existentes entre ele e as lideranças locais e do PCB. Preocupava-os, isto sim, o rumo que a política estadual e nacional parecia tomar. Em Belo Horizonte, o governador Magalhães Pinto recebia no Palácio do Governo algumas das lideranças dos grupos de esquerda, como o presidente da SUPRA/MG (Superintendência da Reforma Agrária, órgão criado do governo federal), o advogado Antonio de Oliveira Lins. Enquanto isso, falava-se que Jango faria um grande comício, no Rio de Janeiro, onde seria regulamentada a lei de reforma agrária.

Ora, uma alteração na estrutura fundiária era algo que subverteria uma tradição secular na história do país. Como dito anteriormente, a extensão da legislação trabalhista urbano-industrial para o campo já garantira aos trabalhadores agrícolas direitos antes inexistentes. Independentemente de seu real alcance, o processo de mobilização e de organização política dos setores subalternos, no campo e na cidade, em todo o país, assim como a mobilização estudantil e o crescimento das esquerdas, eram vistos como ameaças à continuidade do modo latifundista de viver. Antes que a guerra estivesse perdida, as diferentes Associações Rurais do estado deram início a uma série de comícios e concentrações não apenas na região do Vale do Rio Doce e do Mucuri, mas também na Zona da Mata e no Sul de Minas. Muitas delas contaram com a presença do governador da Guanabara, dos bispos de Valadares e de Caratinga, do reverendo Pedro Alves de Aguiar, representante das Igrejas Evangélicas, e de políticos do PSD, da UDN, do PR e do PSP. ${ }^{31}$

Em meio a esse processo de polarização das posições políticas, crescia o número de sindicalizados na ex-sapataria do Chicão. A essa altura, duas ou- 
tras fazendas, além da Fazenda do Ministério, passaram a ser alvo dos sindicalizados da região. Desconfiados de que as terras de apenas uma propriedade seriam insuficientes para tantos pretendentes, decidiram tomar tanto a fazenda da ANGLO (empresa de refrigeração de carnes), quanto a antiga fazenda da Grã-Duquesa de Luxemburgo, cujos terrenos localizados nas imediações da cidade vinham sendo loteados e vendidos pela Prefeitura Municipal.

Certo é que o clima na cidade estava se tornando cada dia mais tenso. Os proprietários consideravam-se desamparados pelo chefe executivo mineiro que, segundo eles, apoiava a "ação dos comunistas da SUPRA"; os sindicalizados viam com reservas toda e qualquer ação que previa a aprovação da justiça. Com isso, a idéia da reforma agrária na lei ou na marra ia se fortalecendo cada vez mais.

Nesse quadro de incerteza e nervosismo, um acontecimento inesperado funcionou como sinal de alerta para a montagem, em Governador Valadares, de uma ação paramilitar. Correu a notícia de que no município vizinho, Galiléia, um grupo de trabalhadores rurais quase enterrara vivo um proprietário da região.

Conta-nos Sr. Sebastião, um dos acusados de pretender a morte daquele fazendeiro, que a "coisa" não se passara da maneira como foi contada:

é uma coisa que eles imputaram em nós, entendeu? Pra meio de prejudicá e até matá, talvez, nós. Lá em Valadares eles falaram que nós fizemo cova; cova pra enterrar o Doma vivo, não foi isso. O que nós dissemos pra ele é: oh! Doma, ocê tá acostumado e ocê gosta é disso, num é? É de colonhão [capim colonião] pra arrumá vaca e bebê leite ... Agora, nós veve não é disso não. Nós veve é disso que tá aqui: e o Paulo Preto meteu o enxadão no chão e rançou uma touça de colonhão e falou pra ele, nós precisa é de terra pra plantá, pra nós colhê e tratá de nossos filhos. Ele que era valente, pegou a correr morro abaixo e nós ficamo ali, rindo que só vendo ... Depois eles enrolaram a história toda e imputaram essa coisa em nós. ${ }^{32}$

Somos levados a crer que naquele momento o fazendeiro sentiu-se realmente ameaçado de morte. Ao ver um empregado rural cravar o "enxadão" no chão e dele retirar "uma touça de colonhão" — símbolo da pecuária extensiva e do uso da terra não como "paiol do chão", como queriam os camponeses, mas como "terra de exploração" - , aquele ex-camponês traduzia em atos sua recusa a ter que continuar a viver sob uma identidade que lhe era imputada de fora para dentro. Simbolicamente, ele e seus companheiros ri- 
tualizavam uma declaração de guerra à forma como o modo capitalista de viver tomara conta das áreas rurais. Ou seja, de como a cultura e a temporalidade camponesa vinham sendo substituídas por outro tempo social. Doma, o proprietário rural em questão, representava não apenas a negação do modo de vida camponês, como também simbolizava a reedição de uma situação de violência mais que secular nas áreas rurais do país.

A partir desse momento, a Associação Rural "exigiu” a presença do poder público, seu aliado secular, na cidade. Em menos de 48 horas chegou a Governador Valadares uma comissão composta por um major do ID-4 (comando militar de Minas Gerais), um representante da Secretaria de Segurança Pública e um representante da Secretaria do Trabalho. Instalados no $6^{\circ} \mathrm{Ba}-$ talhão da Polícia Militar, esses representantes do poder público estadual entraram em entendimento com o presidente e o secretário da Associação e com o delegado local..$^{33}$

Relata-nos o presidente da Associação Rural que o sentimento da classe era de que "os comunistas e sindicalistas contavam com mais apoio do governo que os ruralistas”. Herdeiros de uma tradição autoritária e excludente, consideravam inaceitável que os representantes do poder público tivessem ido a Governador Valadares para ouvir e dialogar também com o presidente do Sindicato dos Trabalhadores Rurais, o Chicão. Afinal, "nem trabalhador rural aquele sapateiro era". Pior ainda, comandava um "sindicato cheio de gente das favelas da cidade". Os mesmos, diríamos nós, que, décadas antes, haviam cedido espaço para as patas dos bois.

Sentindo-se abandonados pelo poder público civil, tentaram encontrar apoio do representante das forças armadas que integrava aquela comissão enviada pelo governador Magalhães Pinto. Conforme relato do presidente da Associação Rural,

À noite, eu disse ao major da ID-4: Major, sinto que estamos perdidos. Ele então bateu no meu ombro e disse: 'não se esmoreça, continue sempre tendo confiança neste verde-oliva' ... E, de fato, as únicas pessoas que nos deram apoio foram o General Guedes e o Comandante do II Exército, Amauri Kruel. ${ }^{34}$

Dois meses após o episódio de Galiléia e da visita dessa comissão, chegou à cidade outra delegação de representantes do governo federal e estadual, composta pelo presidente da SUPRA/MG, Dr. Antonio Lins, o Secretário do Trabalho, Dr. Edgar da Mata Machado, e o Secretário do Governo de Minas, Sr. José Aparecido de Oliveira. ${ }^{35}$ 
Com os ânimos já exaltados, o presidente da Associação Rural de Valadares se recusou a assentar-se ao lado "dos comunistas que estavam presentes na mesa”. Referia-se ao representante da SUPRA/MG e ao Secretário do Trabalho. Estava criado o impasse.

A partir daí os fazendeiros não mais solicitaram a presença das autoridades governamentais na cidade. Passaram a agir com as forças que tinham e com os apoios que sabiam reunir.

Sob a autorização do então delegado de polícia da cidade, tenente-coronel Paulo Reis, e a supervisão do Cel. Pedro Ferreira dos Santos e do Cel. Altino Machado - este há muito acusado de ser um dos maiores grileiros da região - , os proprietários constituíram grupos de caça aos comunistas. Silenciosamente formaram um grupo de vinte líderes e estabeleceram o seguinte plano:

Bom, diziam que um grupo de paraquedistas estava sendo enviado para proteger os invasores de terras, então nós nos preparamos para recebê-los. Providenciamos cem caixas de dinamite com o Habib que era comerciante e, simultaneamente, alguém foi ao Rio de Janeiro e trouxe duas metralhadoras colt médias, quatro fuzis springfields e seis fuzis garães. Todos modelos especiais, com três tipos de munição. Nós tínhamos balas contundentes, bala incendiária e balas perfurantes. Chegamos até a conversar também com alguém no Rio, sobre a possibilidade de aquisição de uma bazuca. Essa turminha fechada ficou incumbida de organizar os setores. Um grupo de quinze pra cá, outro de quinze pra lá. Alguns iriam cortar a luz da cidade, outros tomar de assalto o depósito de combustível que ficava atrás da Vila Bretas, assim por diante. Ficamos preparados de uma maneira bem silenciosa, de forma que não transparecesse nada, compreende? ${ }^{36}$

Enquanto isso, a imprensa de todo o país prometia para breve a publicação do chamado decreto de reforma agrária da SUPRA. A 13 de março, durante o famoso comício da Cinelândia, o presidente Goulart declarava diante de cerca de 200 mil pessoas a assinatura do decreto de desapropriação das terras localizadas nas margens dos açudes, das rodovias e ferrovias, bem como dos latifúndios com área superior a 500 hectares.

Apostando na divisão, ou melhor, no enfraquecimento do movimento dos proprietários rurais, já que muitos fazendeiros não seriam atingidos pelo decreto, as lideranças do PCB, e do movimento sindical em geral, deram continuidade à preparação do comício inicialmente marcado para o dia 12 de abril e posteriormente transferido para 31 de março. Nesse ato público se- 
riam entregues aos sindicalizados os títulos de terras correspondentes às fazendas do Ministério, da Anglo e da Grã-Duquesa. Além de representantes dos governos estadual e federal, já haviam confirmado presença vários políticos, lideranças do CGT e sindicalistas locais.

Para os posseiros, assalariados agrícolas e demais ex-camponeses, esse decreto, o apoio dos demais representantes dos setores subalternos, bem como o próprio crescimento dos demais sindicatos rurais da região, simbolizavam a reinstalação da fronteira como bem ilimitado e, conseqüentemente, a possibilidade de concretização da utopia camponesa.

Para os proprietários fundiários, toda aquela movimentação representava o fim do modo latifundista de viver e, conseqüentemente, o término de um pacto secular entre Estado e latifúndio. Diante da possibilidade de perdas tão significativas, com os ânimos por demais exaltados à espera dos paraquedistas que não vinham; os ouvidos atordoados com o movimento de alto-falantes rondando a cidade e conclamando a todos para o comício de entrega de títulos de terras aos camponeses; apreensivos com os boatos sobre novas invasões de terras em Galiléia, em Nanuque e em Carlos Chagas, a liderança dos proprietários rurais não mais se conteve. Em 30 de março, esses proprietários fundiários que também eram médicos, advogados, comerciantes e delegados de polícia reformados dirigiram-se para o bairro Santa Terezinha, local onde funcionava a sede do Sindicato dos Trabalhadores Rurais, dirigido pelo camponês-sapateiro, e abriram fogo sobre os que ali se encontravam.

Assim, "a revolução que estava programada para o dia $1^{\circ}$ de abril, começou dois dias antes em Governador Valadares”, concluiu o Cel. Altino Machado. ${ }^{37}$

\section{CONSIDERAÇÕES FINAIS}

Após 40 anos do golpe de abril de 1964, outra é a situação política do país e da região do Vale do Rio Doce. Em janeiro de 2001 os eleitores de Governador Valadares empossaram um prefeito do Partido dos Trabalhadores, ex-preso político durante a ditadura militar. Dois anos depois, assumia a Presidência em Brasília um ex-metalúrgico de São Bernardo do Campo e um dos fundadores do PT, partido cujo nascimento esteve intimamente ligado à proliferação dos movimentos sociais e às lutas sindicais em fins da década de 1970 e início dos anos 80 . Hoje, pode-se dizer que os enormes desafios econômicos, financeiros e sociais por que passa a sociedade brasileira contam, a seu favor, com a vigência da estabilidade democrática, inexistente no imediato pré-golpe. 
Sua continuidade é condição sine qua non para legitimar os interesses saídos tanto dos mundos do capital, quanto dos universos do trabalho. A vigência das liberdades democráticas é a base necessária para que os diferentes segmentos sociais possam contar com foros adequados para neles exprimir suas demandas e dialogar, em situação de igualdade, com seus opositores.

No que se refere ao universo rural, pode-se dizer que as lutas pelas liberdades democráticas são decorrência da atuação persistente de diferentes atores sociais. Entre eles, há que lembrar a atuação da CONTAG - Confederação Nacional dos Trabalhadores na Agricultura, criada em 1963. Exercendo o papel de mediadora entre as demandas dos sindicalizados e o Estado, essa entidade foi crucial para a sobrevivência dos sindicatos de trabalhadores agrícolas que, ao longo dos anos 70 e 80 , foram se libertando do perfil assistencialista a eles impingido pela ditadura e, simultaneamente, funcionando como canal de denúncia sobre as violências nas áreas rurais e na luta por direitos trabalhistas. Em que pesem as adversidades enfrentadas pela entidade e por seus atores nos anos de chumbo da ditadura, sabe-se que sua atuação tendeu a usar os dispositivos legais - sindicalização e Estatuto da Terra — para vincular a luta por direitos trabalhistas à luta pela terra.

Ainda que os resultados em termos de reforma agrária não tenham sido expressivos, a entidade pode contabilizar, entre seus méritos, o papel de criar as condições legais para o surgimento, entre fins dos anos 70 e o início dos 80 , dos chamados "novos personagens em luta pela terra". Referimo-nos, especificamente, aos atingidos por barragens das regiões onde se construíam novas hidrelétricas; ao movimento dos pequenos produtores rurais, constituído pelos excluídos do processo de modernização da agricultura feita sem qualquer alteração na estrutura fundiária; ao movimento dos seringueiros, que resistiu ao processo de substituição dos seringais da Amazônia por terras de pastagens e, finalmente, ao movimento dos sem-terra, surgido em 1984, com o lema "terra não se ganha, se conquista". ${ }^{38}$

Ora, a atual diferenciação das formas de luta nas áreas rurais coloca-nos diante de uma situação abortada pelo golpe de 1964. O caso dos sindicatos de trabalhadores rurais do Vale do Rio Doce, analisado neste artigo, mostranos a pluralidade do universo rural, naquele momento desconsiderada até mesmo pelas organizações de esquerda. Independentemente dos elos comuns que perpassam a realidade dos chamados "novos personagens do mundo rural", há que reconhecer a retomada da democracia como fator crucial para que esses, e outros atores coletivos, possam continuar a expressar, de dentro para fora, suas identidades socioculturais. O respeito à alteridade é, por sua 
vez, condição para se seguir na busca de estratégias políticas que garantam aos diferentes atores da sociedade uma inserção política e social que tanto lhes permitirá manter suas tradições, quanto lhes possibilitará participar das aquisições materiais e simbólicas em curso.

\section{NOTAS}

${ }^{1}$ Este artigo foi produzido com base nos dados de nossa dissertação de mestrado intitulada: Utopias e contra-utopia: movimentos sociais rurais de Minas Gerais (1954-64), defendida, em dezembro de 1988, no Mestrado em Sociologia da UFMG.

${ }^{2}$ Sobre estas questões, ver CAMBRAIA, R. de B. e MENDES, F. F. A colonização dos sertões do leste mineiro: políticas de ocupação territorial num regime escravista, 1780-1836. Revista do Departamento de História. Belo Horizonte: FAFICH, n.6, p.141 ss, 1988.

${ }^{3}$ Sobre o contexto de criação dessa companhia, bem como sobre sua história, ver: DUARTE, R. H. (Org.) Teófilo Otoni: notícias sobre os selvagens do Mucuri. Belo Horizonte: UFMG, 2002.

${ }^{4}$ Sobre a colonização alemã no vale do Mucuri, ver MATA MACHADO, B. (Org.) A colonização no Vale do Mucuri. Belo Horizonte: Fundação João Pinheiro, 1993. (Coleção Mineiriana, série Estudos e ensaios).

${ }^{5}$ Sobre a construção dessa estrada, ver: SIMAN, L. M. de C. A história na memória (uma contribuição para o ensino da história de cidades). Belo Horizonte: FAE, 1988 (dissertação de Mestrado).

${ }^{6}$ Segundo VELHO, “o locus por excelência da terra 'ilimitada' é a fronteira ... ela é o locus privilegiado para uma ideologia clássica do laissez-faire. Embora na prática, mesmo na fronteira, a terra não esteja realmente aberta a todos sem limite, pode representar uma tal imagem ideológica quando contrastada com outras situações camponesas". No caso do campesinato, a fronteira parece representar em síntese: 1) a possibilidade de uma trajetória ascendente e 2) o enfraquecimento de uma subordinação estrita e imediata. Sobre estas questões, ver VELHO, O. Capitalismo autoritário e campesinato: um estudo comparativo a partir da fronteira em movimento. Rio de Janeiro: Difel, 1976. p.100-1 (grifos do autor).

${ }^{7}$ Entrevista com o Dr. José Tavares Pereira, advogado ruralista e um dos fundadores da Associação Rural de Governador Valadares, 27 ago. 1987.

${ }^{8}$ Entrevista com o Dr. Rubens Alves Barroso, secretário da Associação Rural de Governador Valadares e um dos principais mentores do movimento paramilitar dos proprietários fundiários da região contra o Sindicato dos Trabalhadores Rurais de Governador Valadares em 1964. Governador Valadares, 28 ago. 1986. 
${ }^{9}$ Entrevista com o Sr. Walter Cipriano, fiscal de mata da Secretaria de Agricultura do Estado de Minas Gerais, entre 1947 e 1968. Entrevista concedida à professora Lanna Mara Siman.

${ }^{10} \mathrm{O}$ caso do Brasil e da região em questão permite uma comparação com os estudos que Weber desenvolve sobre as razões do autoritarismo na Prússia, onde o avanço do capitalismo para as áreas rurais não foi permeado pela agricultura comercial. Ali, assim como no Brasil e no Japão (cujo caso foi objeto de análise de B. Moore), a modernização da economia rural foi fruto de uma "revolução vinda de cima". Entre os desdobramentos de tais particularidades está o alto grau de exclusão social, a constante instabilidade democrática e a permanência de uma cultura fortemente autoritária. Sobre essas questões, ver WEBER, M. Capitalismo e sociedade rural na Alemanha; O caráter nacional e os Junkers. In: Ensaios de Sociologia. 5.ed. Rio de Janeiro: Zahar, 1979; e MOORE, B. As origens sociais da ditadura e da democracia: senhores e camponeses na construção do mundo moderno. Lisboa: Cosmos, 1967.

${ }^{11} \mathrm{O}$ termo assalariado rural é aqui utilizado para indicar as diferentes formas de trabalho no campo. Todavia, há que lembrar que o Estatuto do Trabalhador Rural só foi criado em novembro de 1962, o que significa que esse assalariado da região carecia dos direitos trabalhistas vigentes para o assalariado urbano. É importante observar que, em geral, sua condição de assalariado não fazia desse trabalhador um operário rural. Seus hábitos e formas de ver o mundo continuavam a inseri-lo no universo da cultura camponesa.

${ }^{12}$ Sobre essas denúncias ver SANTAYANA, M. "Enquanto os posseiros são expulsos e assassinados, seus filhos morrem de fome”, Diário de Minas, 5 abr. 1957, p.5; “Somente os protegidos políticos registram terras na Secretaria de Agricultura”, Diário de Minas, 7 abr. 1957, p.8; e “A situação no Rio Doce”, Diário de Minas, 3 nov. 1957, p.4.

${ }^{13}$ Sobre as referências ao cangaço e demais movimentos sociais no campo, ver SANTAYANA, M. “Enquanto os posseiros...”, cit.

${ }^{14}$ Entrevista com o Sr. Otávio Abrantes, presidente da Associação Rural de Governador Valadares, 1963-64. Belo Horizonte, 14 jan. 1987, grifos nossos.

${ }^{15}$ MARCÍlIO, Á. O problema das terras devolutas e suas matas no Estado de Minas. Belo Horizonte: Estab. Gráf. Santa Maria, 1961. p.15.

${ }^{16}$ Ibidem.

${ }^{17} \mathrm{O}$ chamado caso Graciliano Tales dos Santos, pendente desde 1950 na região de Itambacuri; o caso Tenente-Coronel João Lopes de Oliveira, no município de Ataléia; o caso Horácio Luz em Itambacuri e outros, ou já haviam sido resolvidos ou estavam aguardando provas complementares para serem apreciados e decididos. Os nomes desses conhecidos grileiros da região eram apresentados como "provas irrefutáveis do rigor e da imparcialidade da lei”. Ver MARCÍLIO, 1961, p.38-46. 
${ }^{18}$ THOMPSON, E. P. Tradición, revuelta y consciencia de clase. Barcelona: Crítica, 1979, p.354.

${ }^{19}$ Sobre a morte de Horácio Luz e sobre o julgamento dos acusados, ver Binômio, 14 ago. 1961, p.4, e Diário do Rio Doce, 3 abr. 1962, p.6.

${ }^{20}$ Há farta documentação sobre as reportagens no Diário do Rio Doce. Eis alguns: 15 ago. 1961, p.3; 10 jan. 1962, p.3; 27 mar. 1962, p.2, e 26 jan. 1962, p.1. Sobre a concentração ruralista, ver Diário do Rio Doce, 17 fev. 1962, p.3; 18 fev. 1962, p.3, e 26 fev. 1962, p.3.

${ }^{21}$ Cabe esclarecer que os setores subalternos do campo eram vistos pela militância do PCB e da AP como parceiros menores do fortalecimento do proletariado que, sob a direção dos trabalhadores industriais-urbanos, iriam conduzir a Revolução Socialista. A proletarização rural, expressa pelo sindicalismo rural, era vista por essas lideranças das esquerdas como uma etapa necessária para a Revolução que poria fim ao latifúndio. Já as Ligas Camponesas, constituídas por posseiros e meeiros, defendiam a luta pela Reforma Agrária na lei ou na marra, como condição sine qua non da luta pela implantação de nova sociedade.

${ }^{22}$ Chamamos "Utopia camponesa” ao desejo de possuir terra para nela construir um modus vivendi calcado em valores próprios da cultura camponesa, expresso nas falas dos camponeses locais ao longo deste artigo.

${ }^{23}$ Ata da reunião ordinária da Câmara Municipal de Governador Valadares, 6 maio 1963, livro 15, p.136.

${ }^{24}$ Entrevista com o Sr. Raimundo Ferreira de Carvalho, membro do Sindicato dos Trabalhadores na Extração da Mica e um dos organizadores do Sindicato dos Trabalhadores Rurais de Governador Valadares. Governador Valadares, 10 out. 1987, grifos nossos.

${ }^{25}$ Ibidem.

${ }^{26}$ Cabe lembrar que o primeiro indício da presença de militantes comunistas no Vale data de meados dos anos 50. Por volta de 1955 foi criada a Associação dos Lavradores e Trabalhadores Agrícolas de Pedra Corrida, município de Açucena, cujo presidente era um posseiro, Sr. Olímpio Malaquias, que vivia da venda de carvão vegetal e pertencia ao PCB. Sabese, também, que já em 1953 vivia em Valadares um advogado, Dr. Caio Monteiro Barros, que defendia algumas causas de posseiros contra grileiros. Pelo que pudemos constatar, este não tinha vínculos com o partido, embora fosse seu simpatizante. Na realidade, a presença do PCB no meio rural tornou-se mais visível a partir da criação do jornal O Saci, dirigido por Carlos Olavo da Cunha Pereira, o qual contava com a colaboração de um outro advogado, também filiado ao PCB, Dr. Plínio Mendes Martins, que usava a imprensa para denunciar os atos de violência contra os camponeses da região. Em 1958, o jornal muda de nome, passa a se chamar O Combate. Suas denúncias por certo irritavam os latifundiários da região, mas dificilmente chegaram a provocar um efeito organizador junto aos homens do campo. Em 1964, esse jornal, impresso em letras vermelhas, foi empastelado e sua sede totalmente destruída por um grupo paramilitar a serviço dos proprietários fundiários locais. 
${ }^{27}$ Entrevista com o Sr. Mamede de Carvalho, presidente do Sindicato dos Trabalhadores Rurais de Santa Cruz, 1964. Santa Cruz, 26 ago. 1986, grifo nosso.

${ }^{28}$ Sobre essas questões, ver BORGES, M. E. L. Estilistas urbanos do universo rural: o PCB na luta pela sindicalização rural em Minas Gerais. Revista Brasileira de História (Brasil 1954-1964). São Paulo: Marco Zero/Anpuh/Fapesp/CNPq, n.27, p.73-86, 1994.

${ }^{29}$ Nos anos 40, o governo Vargas doara ao governo de Minas Gerais uma área, localizada próximo a Governador Valadares, para funcionar como fazenda modelo na região. A idéia era que nesse local funcionasse um centro de pesquisa agropecuária e de treinamento para o uso de novas tecnologias. Com o passar do tempo, a chamada Fazenda do Ministério se tornou um local de empréstimo de tratores e outros tipos de maquinário agrícola para os proprietários fundiários da região.

${ }^{30}$ Entrevista com Ivanor Nunes de Oliveira, diretor do jornal estudantil O Olho (1962-63). Belo Horizonte, 7 dez. 1987, grifo nosso.

${ }^{31}$ Sobre essas concentrações ver Diário do Rio Doce, 8 jun. 1963, p.1; 11 jun. 1963, p.1; 14 jun. 1963, p.1 e 3; 30 jun. 1963, p.1, e 12 jul. 1963, p.1.

${ }^{32}$ Entrevista com o Sr. Sebastião Silveira de Oliveira, membro do Sindicato dos Trabalhadores Rurais de Santa Cruz, município de Galiléia.

${ }^{33}$ Entrevista com o Sr. Otávio Abranches, cit.

${ }^{34}$ Ibidem, grifo nosso.

${ }^{35}$ É abundante o material publicado na imprensa local, estadual e nacional sobre os antecedentes e os desdobramentos desse encontro ocorrido na Associação Comercial de Governador Valadares. Apenas para citar alguns, ver "Comércio contra João Pinheiro Neto", Diário do Rio Doce, 5 fev. 1964, p.1; "Ministro determinou colonização da fazenda”, Diário do Rio Doce, 4 fev. 1964, p.1; "Pinheiro Neto volta a Valadares determinando desapropriação da Anglo", Diário de Minas, 5 fev. 1964, p.4.

${ }^{36}$ Entrevista com o Dr. Rubens Alves Barroso, cit.

${ }^{37}$ Entrevista com o Cel. Altino Machado, ex-delegado de polícia, ex-funcionário da BelgoMineira, proprietário rural e um dos principais coordenadores do movimento paramilitar de Governador Valadares.

${ }^{38}$ Sobre a história desses movimentos, ver MEDEIROS, L. S. História dos movimentos sociais no campo. Rio de Janeiro: Fase, 1989. 